International Research Journal of Engineering, IT \& Scientific Research
Available online at https://sloap.org/journals/index.php/irjeis/
Vol. 5 No. 1, January 2019, pages: 39 49
ISSN: 2454-2261
https://doi.org/10.21744/irjeis.v5n1.596

\title{
The Effect of Love of Money and Emotional Intelligence on Employee Performance with Organizational Citizenship Behavior as Mediating Variable
}

\author{
Ni Putu Widiani ${ }^{\text {a }}$ \\ I Gst. Ayu Made Asri Dwija Putri ${ }^{\text {b }}$ \\ Maria Mediatrix Ratna Sari ${ }^{\mathrm{c}}$ \\ I Gde Ary Wirajaya ${ }^{d}$
}

Article history:

Received: 27 July 2018

Accepted: 30 November 2018

Published: 30 January 2019

\section{Keywords:}

$B P R$;

emotional intelligence;

employee performance;

love of money;

organizational citizenship

behavior;

\begin{abstract}
The variables used in this study design are the first exogenous variables (exogenous) a love of money, organizational citizenship behavior, and emotional intelligence. Endogenous variables (endogenous) are employee performance. The population in this study were all employees in 51 BPRs in Badung Regency in 2018 where the returned questionnaires were 117. Data analysis in this study used the Partial Least Square (PLS) approach using SmartPLS software. The results of this study are, 1) Love of money has a negative effect on organizational citizenship behavior, 2) emotional intelligence has a significant positive effect on organizational citizenship behavior, 3) love of money does not directly influence employee performance, 4) emotional intelligence has a positive effect significant influence on employee performance has a significant positive effect on employee performance, 6) Organizational citizenship behavior (OCB) mediates the effect of love of money on employee performance, 7) Organizational citizenship behavior (OCB) mediates the influence of emotional intelligence on employee performance.
\end{abstract}

2454-2261 ${ }^{\odot}$ Copyright 2019. The Author. This is an open-access article under the CC BY-SA license (https://creativecommons.org/licenses/by-sa/4.0/) All rights reserved.

\section{Author correspondence:}

Ni Putu Widiani,

Post Graduate Program of Udayana University, Bali

Email address: n.widiani30@yahoo.com

\section{Introduction}

Bank Perkreditan Rakyat (BPR) (rural bank) has become part of the nation's economic development. The existence of BPR has spread throughout the regencies/cities in Indonesia, one of which is in Bali. Bali is one of the provinces in Indonesia with the development of the third largest number of BPR assets in Indonesia. The magnitude

${ }^{a}$ Economics and Business Faculty, Post Graduate Program of Udayana University, Denpasar, Bali, Indonesia

${ }^{\mathrm{b}}$ Accountancy Department of Economics and Business Faculty of Udayana University, Denpasar, Bali, Indonesia

${ }^{c}$ Accountancy Department of Economics and Business Faculty of Udayana University, Denpasar, Bali, Indonesia

${ }^{\mathrm{d}}$ Accountancy Department of Economics and Business Faculty of Udayana University, Denpasar, Bali, Indonesia 
of the role held by BPRs and the increase in sources of funds managed by BPR are unfortunately not yet in line with the improvement in the performance of BPR employees. However, research by Sayekti \& Kartika (2015), found that the current performance of BPRs was not optimal, judging from the overall quantity, there were only $78.3 \%$ of BPRs that met the minimum requirements for directors and commissioners. While in terms of quality, many perceptions state that the quality of BPR HR is relatively low. This result is supported by the findings of Gede \& Piartini (2018); and Bastian (2017).

There are three factors that affect the performance of employees or employees according to Simanjuntak (2011), first individual competency factors, organizational support factors, and the third factor is management support. Sayekti \& Kartika (2016), found that the performance of BPR employees who were not optimal was caused by less competent Human Resources (HR). BPRs find it difficult to get quality human resources because the compensation provided is less attractive. Money is very important with individual attitudes that can be seen through personality, biography, and attitude variables (Mitchell \& Mickel, 1999) so that this will be related to the love of money called the love of money.

The performance of BPR employees is also influenced by emotional intelligence and organizational citizenship behavior (OCB). Emotional intelligence and OCB are variables that are widely discussed by experts, because their existence is considered to have a direct impact on the performance of individuals and organizations, both in the public sector and in the private sector (Ibrahim, 2013).

Emotional intelligence is the ability to recognize feelings of self and others, foster self-motivation, and manage emotions in interacting with others (Goleman, 2006). The results of Trihandini (2005) provide empirical evidence compared to intellectual intelligence or spiritual intelligence, emotional intelligence has the greatest influence.

Organizational citizenship behavior (OCB) is defined as individual behavior that is recognized as a formal reward system explicitly and will encourage organizational functions in a more effective direction (Organ, 1988). The success of an organization depends on the willingness of employees to work beyond the responsibilities of their duties and provide time and energy for the successful implementation of tasks voluntarily.

Research on the influence of the love of money, emotional intelligence, and OCB has been done before, but the results are inconsistent. Although Sayukti \& Kartika (2016), suggest that BPRs increase compensation for their employees so that performance improvements can be achieved which means that love of money will improve employee performance, but Martini et al., (2017), research prove the opposite. Martini et al., (2017), found that Love of money had no effect on employee performance. The inconsistency of results is also seen in emotional intelligence. Even though Martini et al., (2017), found that emotional intelligence had a significant effect on performance, but the findings by Akimas \& Bachri (2016), showed that emotional intelligence had no significant effect on employee performance.

\section{Materials and Methods}

The relationship between Love of money towards Organizational citizenship behavior can be explained by Theory of Planned Behavior (TPB) and motivation theory. The amount of money and income earned by someone is used as a measure of one's success (Ellias, 2009). Herzberg (1987), said that money is a motivator for some people, but others consider it a hygiene factor. The concept is used to estimate one's subjective feelings about money. Individual performance affects team performance, which in turn affects organizational performance in general.

Herzberg (1987), said that money is a motivator for some people, but others consider it a hygiene factor. The concept is used to estimate one's subjective feelings about money. Individual performance affects team performance, which in turn affects organizational performance in general. Individual behavior that is demanded by the organization is not only in role behavior but also extra-role behavior, extra-role behavior is often referred to as Organizational Citizenship Behavior (OCB).

Someone who has an attitude of love for excess money will consider money as a need that must be met and will do various ways to get money (Robbins \& Judge, 2007; in Novianidan Andri, 2014). High perceptions of the love of money will reduce ethical behavior while low perceptions of the love of money will increase ethical behavior. Ethical behavior in question is positive employee behaviors in building organizations such as voluntary actions to work optimally, tolerance and other disciplinary actions that are part of organizational citizenship behavior. A person's perception is influenced by his ethics. When his love of money is able to be fulfilled by the company where he works, he will always try to survive, but the nature of human beings causes an individual to tend to always have a desire that is never satisfied in an achievement including the desire for financial achievement. So that when an 
employee feels that the company has not been able to fulfill his sense of love for money, his intention to switch to a company that is able to fulfill his love will continue to roll. Based on the above explanation, the hypothesis of the love of money relationship on employee performance is as follows:

The relationship between emotional intelligence to organizational citizenship behavior can be explained by the Theory of Planned Behavior (TPB). The company or organization is a place or place for the gathering of individuals who have goals both in dividends or groups. Organizations have a significant influence on the people who work for them and some of their effects are reflected in how people feel about their work (Spector, 1997).

Hardaningtyas (2004), research where emotional intelligence influences organizational citizenship behavior, which implies that the more emotional someone's intelligence increases the more organizational citizenship behavior. Based on the results of a study conducted by Jung \& Hye (2011), it was shown that emotional intelligence had a positive and significant effect on the Organizational citizenship behavior of employees. Based on the results of factor analysis shows that emotional intelligence is an important factor in improving organizational citizenship behavior. Employees who understand, control, and use emotions effectively will create a work environment that is positive and significant in enhancing employee behavior such as improving organizational citizenship behavior.

The research conducted by Anindya (2011), shows that emotional intelligence has a positive and significant effect on Organizational citizenship behavior of Kompas Gramedia's department X unit employees. The higher the emotional intelligence of employees, the higher the organizational citizenship. Setyawati (2012), research shows that the level of emotional intelligence is considered the most capable factor to stimulate the formation of the Organization Citizenship Behavior (OCB) of employees of PT. PLN (Persero) Purwokerto Service and Network Area (APJ) compared to other factors such as employee attitudes towards organizational culture. Ibrahim (2013), emotional intelligence had a significant effect on OCB nurses at Anutapura General Hospital and Undata Hospital in Palu. That means, the more nurses 'ability to motivate themselves accompanied by high self-awareness, it will be followed by an increase in nurses' OCB behavior. Based on the above explanation, the hypothesis of the relationship of emotional intelligence to Organizational Citizenship Behavior is as follows:

According to Tang \& Chiu (2003), someone who has a love of high money (high love of money) will be more motivated to take any action to get more money. Employees with a love of high money will be motivated to work as much as possible to fulfill their desires for money so that when employees feel that their love of money has been fulfilled, their work ethic will increase which directly enhances the performance of employees. Liu \& Tang's (2011), research has also found results that love for money (high love of money) has a positive effect on employee motivation to work. Based on the description above, the relationship between the love of money on employee performance is as follows:

In the context of work, emotional intelligence (EQ) is an ability to know what we and others feel, including the right way to solve a problem. Other people referred to here are superiors, co-workers, subordinates, and violations. Goleman (2003), states that emotional intelligence can foster empathy, love, motivation, and ability to respond or respond to happiness or sadness. Lebi continued Salovey (in Goleman, 2003) explaining that one aspect of emotional intelligence is motivation.

Fabiola's (2005), research shows that emotional intelligence has a significant effect on performance. Based on the research conducted by Hardiat (2016), (studies on marketing employees of PT. Nasmoco Bahana Motor in the city of Yogyakarta) found that Emotional intelligence had an effect on employee performance. The results of these studies have been in line with the results of previous studies such as Rahmasari (2012); Sella (2011); Wibowo (2015) and Nuraningsih (2015), who found that there was a positive and significant effect of emotional intelligence on employee performance. Based on the above description, the hypothesis of the relationship between emotional intelligence on employee performance is as follows:

The success of an industry is not only determined by the behavior of employees who are determined according to their job description (in-role behavior) but also the behavior of employees that are outside the work description (extra-role behavior). OCB is individual behavior that is free and explicitly gets an award from a formal reward system, and overall encourages the effectiveness of organizational functions (Organ \& Lingl, 1995; Organ, 2015). Research Hui et al., (2000), concluded that organizations that want employees to do things or work beyond the job description have proven advantages over other companies. Therefore, many companies want their employees to have OCB. Purba \& Seniati (2004), argue that the benefits of OCB are increasing work productivity. Previous studies have examined the effect of OCB on employee performance including the research conducted by Nufus (2011); Ticoalu (2013), who tested the effect of OCB on performance, where the results of this study showed that OCB had a significant influence on employees. Furthermore, Gunawan's (2013), research has also found that OCB has a positive

Widiani, N. P., Putri, A. M. A. D., Sari, M. M. R., \& Wirajaya, I. G. A. (2019). The effect of love of money and emotional intelligence on employee performance with organizational citizenship behavior as mediating variable. International Research Journal of Engineering, IT \& Scientific Research, 5(1), 39-49. 
effect on job satisfaction and employee performance. The study was also supported by Lestari et al., (2015), research who also found that OCB had a positive and significant effect on job satisfaction and employee performance. The higher the OCB of an employee, the higher the satisfaction and performance of the employee. Based on the description above, the hypothesis of Organizational Citizenship Behavior relations on employee performance is as follows:

Every organization is required to always improve performance and effectiveness in order to survive globalization. One important element that is considered capable of improving organizational performance and effectiveness is the willingness of employees to perform extra-role performance in addition to performance in roles. Organ et al., in Garay (2006), named the performance of extra roles in terms of Organizational Citizenship Behavior (OCB). According to Lawler (2000), states that the system of wages or salaries can act as an agent of change for the organization. In other words, when an organization expects a new/additional behavior to occur, performs an extrarole performance, from the company's performance then compensation policies can be used as a tool to foster that behavior. Money is an important thing in life (Elias, 2010), by reminding money as a reward that someone will work harder and try to take more jobs than people who are not reminded of money in return (Vohs et al., 2008). Nonetheless, Tang et al., (2008), stated that someone who has a high love for money is associated with extrinsic motives and helpful behavior. Helpful behavior is closely related to aspects of Organizational Citizenship Behavior (OCB). So that when someone has a high love of money, this will affect OCB, which is an important factor in improving employee performance, so it is assumed that the effect of the love of money on employee performance will be intervened by the presence of OCB. Based on this, the hypothesis is formulated.

The influence of emotional intelligence on performance can be intervened by the state of Organizational Citizenship behavior (OCB). Based on the Theory of Planned Behavior, someone who has a high intention to advance an organization (company) will always show good performance in accordance with their duties and responsibilities. Every individual in an organization that has good emotions tends to have the willingness to improve and improve its performance, as stated by Goleman (2005), where emotional intelligence has a positive significant influence on performance which means that the higher emotional intelligence a person has, the higher his performance Emotional intelligence can not only affect employee performance achievement, but emotional intelligence can also influence the employee's OCB. Organizational citizenship behavior (OCB) is employee behavior that exceeds the demands of his work. The research conducted by Janis (2013), said that there was a significant positive relationship between emotional intelligence and OCB where the higher the person's emotional intelligence, the higher the organizational citizenship behavior (OCB) of the person. Financial performance is influenced by OCB so that emotional intelligence will influence financial performance through OCB (Pratama, 2016). Based on this, the hypothesis is formulated.

Hypothesis:

H1: Love of money has a negative effect on Organizational citizenship behavior

H2: Emotional Intelligence has a positive effect on Organizational citizenship behavior

H3: Love of money has a positive effect on the performance of BPR employees in Badung Regency

H4: Emotional intelligence has a positive effect on the performance of BPR employees in Badung Regency.

H5: Organizational citizenship behavior has a positive effect on the performance of BPR employees in Badung Regency.

H6: Organizational citizenship behavior mediates the effect of the love of money on the performance of employees at BPR in Badung Regency

H7: Organizational citizenship behavior mediates the influence of emotional intelligence on employee performance at BPR in Badung Regency

The population in this study were all employees in 51 BPRs in Badung Regency in 2018. The sampling method used by researchers was accidental sampling by taking samples that happened to exist (Nasution, 2006). The number of samples required is a minimum of 10 to 20 times the number of variables (Roschoe, 1975 in Halim \& Ishak, 2014). So that the target is a minimum sample of 80 respondents. The returned questionnaire was 117 questionnaires or $100 \%$. All questionnaires in this study were responded to and complete, so there were no questionnaires that were not responded to or incomplete. So that the total questionnaire returned and can be used is 117 questionnaires or equal to $100 \%$. Data analysis in this study used the Partial Least Square (PLS) approach using SmartPLS software. Figure 1 below is a picture of a research model on this research. 


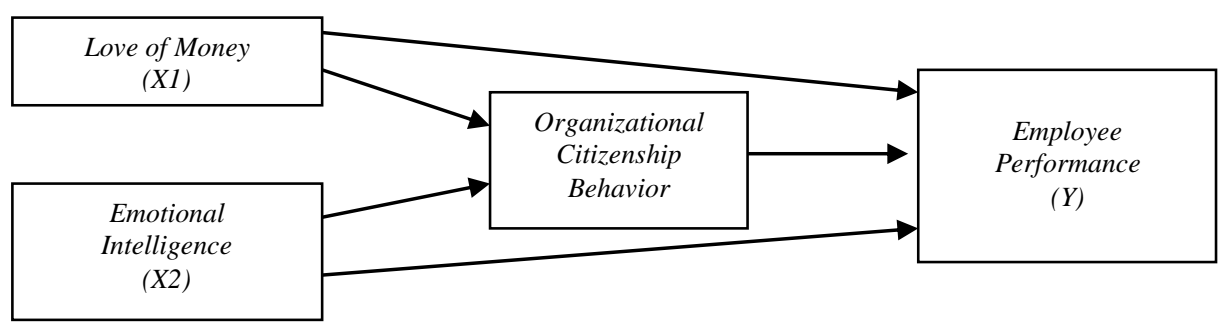

Figure 1. Research Model

\section{Results and Discussions}

The significance of the estimated parameters provides very useful information about the relationship between the research variables. The basis used in testing hypotheses is the value found in the result for inner weight output. Table 1 provides the estimated output for testing structural models.

Table 1

Inner weight test results

\begin{tabular}{lcccc}
\hline \multicolumn{1}{c}{ Inter-Variable Relationships } & $\begin{array}{c}\text { Original } \\
\text { Sample }\end{array}$ & $\begin{array}{c}\mathrm{T} \\
\text { Statistics }\end{array}$ & P Values & Conclusion \\
\hline $\begin{array}{l}\text { Organizational citizenship behavior -> Employee } \\
\text { performance }\end{array}$ & 0,944 & 16,833 & 0,000 & Significant \\
$\begin{array}{l}\text { Love of money -> Organizational citizenship behavior } \\
\text { Love of money -> Employee performance }\end{array}$ & $-0,654$ & 14,050 & 0,000 & Significant \\
$\begin{array}{l}\text { Emotional Intelligence -> Organizational citizenship } \\
\text { behavior }\end{array}$ & 0,089 & 1,057 & 0,291 & Not significant \\
Emotional Intelligence -> Employee performance & 0,042 & 3,574 & 0,000 & Significant \\
\hline
\end{tabular}

In the PLS a statistical test of each hypothesized relationship is carried out using simulation. Based on the results of statistical tests, the following can be concluded:

Love of money has a negative effect on organizational citizenship behavior in BPR Badung Regency so that this shows that the higher the love of employees towards the lower organizational citizenship behavior of the employee towards the company where he works. So when in a condition the employee feels his desire for the love of money is not able to be fulfilled in the organization where he works, then there is a tendency for these employees to always move to other companies that are considered capable of fulfilling love desires for money.

Emotional intelligence has a significant positive effect on organizational citizenship behavior at BPR in Badung Regency. This means that the higher the emotional intelligence possessed by employees, then organizational citizenship behavior will also increase. This indicates that when an employee has good emotional intelligence, then the employee will show a high love for the organization or company where he works.

Love of money does not directly affect the performance of employees in BPR Badung Regency so that this shows that money is not the best motivation so Love of money cannot affect employee performance. The results of this study, which found that love of money does not affect the performance of BPR employees in Badung Regency can also occur because the respondents in this study were mostly young and unmarried and had no dependent children. After modifying the structure model, the indicator used to explain the influence of the love of money on employee performance is a success, self-expression, social influence, happiness, and motivator. At a relatively young age, money tends not to be considered evidence of one's success and is not the main way for young employees to express themselves. In addition, at a young age, people tend not to have the desire to have high social influence besides that the younger generation is now beginning to realize that money is not a source of happiness and the main motivation to improve performance.

Widiani, N. P., Putri, A. M. A. D., Sari, M. M. R., \& Wirajaya, I. G. A. (2019). The effect of love of money and emotional intelligence on employee performance with organizational citizenship behavior as mediating variable. International Research Journal of Engineering, IT \& Scientific Research, 5(1), 39-49. https://doi.org/10.21744/irjeis.v5n1.596 
Emotional intelligence has a significant positive effect on employee performance at BPR in Badung Regency. This means that the higher the emotional intelligence possessed by employees, the higher the employee's performance. Based on the data obtained in this study, the indicators on emotional intelligence variables have high scores, this means that BPR employees in Badung Regency have high emotional intelligence so that they are expected to be followed by improving their performance. While in terms of employee performance, indicators of commitment, especially on items about employee loyalty, have a moderate score. This can occur as a result of the majority of respondents are classified as young employees, namely in the age range under 30 years and have a working period of under three years. Employees who have a younger age and work periods that are not too long will generally be more open to more promising offers for their career advancement.

Organizational citizenship behavior (OCB) has a significant positive effect on employee performance at BPR in Badung Regency. This means that the higher the OCB, the employee's performance will increase. The results of this study support the study of Gunawan (2013); Ticoalu (2013); Lestari et al., (2015); and Martini et al., (2017), who found that Organizational Citizenship Behavior had a significant positive effect on employee performance. The higher the OCB of an employee, the higher the performance of the employee.

Organizational citizenship behavior (OCB) mediates the effect of the love of money on the performance of employees in rural banks in Badung Regency. The mediating nature of OCB in the influence of emotional intelligence on employee performance is fully mediated. The results of this study confirm the statement of Tang et al., (2008), where the coefficient of the love of money towards OCM has a negative value. On the side of love of money, Tang et al., (2008), stated that someone who has a high love for money is positively related to extrinsic motives that are negatively related to helping behavior. Helpful behavior is part of OCB, which will later affect employee performance as part of the organization.

Organizational citizenship behavior (OCB) mediates the influence of emotional intelligence on employee performance in rural banks in Badung Regency. The mediating nature of OCB in the influence of emotional intelligence on employee performance is partially mediated. The results of this study support the research conducted by Janis (2013) who found that there was a positive significant relationship between emotional intelligence and OCB where the higher one's emotional intelligence, the higher the organizational citizenship behavior (OCB) of the person. Financial performance is influenced by $\mathrm{OCB}$ so that emotional intelligence will influence financial performance through OCB (Pratama, 2016).

\section{Conclusion}

Based on the results of the study, there are several suggestions that can be given to the management of BPR, especially BPR in Badung Regency. BPR management so that not only fixes on monetary rewards, but also considers the provision of non-monetary rewards consisting of growth, job security, interpersonal relations, and challenging work tasks in an effort to improve employee performance. Love of money does not affect employee performance so money is not the best factor to encourage employee performance. Money is an extrinsic factor whereas than extrinsic factors, well-maintained intrinsic motivation factors that actually have a positive and significant influence on job performance.

This result encourages companies, especially BPRs, not only to fix monetary rewards, but also to consider nonmonetary rewards consisting of growth, job security, interpersonal relations, and challenging work tasks in an effort to improve employee performance. In addition, this study shows the importance of emotional intelligence and Organizational Citizenship Behavior (OCB) in improving employee performance so companies need to develop ways and policies that can encourage an increase in employee emotional intelligence and grow OCB for their employees. In an effort to find out the factors that can improve employee performance, further research can be carried out on employee motivation factors, such as growth, job security, interpersonal relations, and challenging work tasks. Further research can also be done on other types of industries and using different performance measurements from this study. 
Conflict of interest statement and funding sources

The authors declared that they have no competing interest. The study was financed by personal funding.

Statement of authorship

The authors have a responsibility for the conception and design of the study. The authors have approved the final article.

\section{Acknowledgments}

The authors would like to thank the editorial team of IRJEIS for their valuable time to support, give an advice in completeng the present article.

Widiani, N. P., Putri, A. M. A. D., Sari, M. M. R., \& Wirajaya, I. G. A. (2019). The effect of love of money and emotional intelligence on employee performance with organizational citizenship behavior as mediating variable.

International Research Journal of Engineering, IT \& Scientific Research, 5(1), 39-49. https://doi.org/10.21744/irjeis.v5n1.596 


\section{References}

Akimas, H. N., \& Bachri, A. A. (2017). Pengaruh Kecerdasan Intelektual (IQ), Kecerdasan Emosional (EQ), Kecerdasan Spiritual (SQ) Terhadap Kinerja Pegawai Inspektorat Provinsi Kalimantan Selatan. Jurnal Wawasan Manajemen, 4(3), 259-272. http://jwm.ulm.ac.id/id/index.php/jwm/article/view/99/99

Antony, J. M. (2013). The influence of emotional intelligence on organizational commitment and organizational citizenship behavior. Journal of Social Science Research, 1(1), 5-8. http://www.academia.edu/download/34179874/Article_published.pdf

Bastian, D. R. (2017). pengaruh kepemimpinan dan budaya organisasi terhadap motivasi serta dampaknya terhadap kinerja karyawan $p d$. bpr kapetakan cirebon (Doctoral dissertation). http://repository.unpas.ac.id/26628/1/ARTIKELdr.doc

Elias, R. Z., \& Farag, M. (2010). The relationship between accounting students' love of money and their ethical perception. Managerial Auditing Journal, 25(3), 269-281. https://doi.org/10.1108/02686901011026369

Garay, L. J. (1995). Quantum gravity and minimum length. International Journal of Modern Physics A, 10(02), 145165. https://doi.org/10.1142/S0217751X95000085

Gede, IK. \& Piartini, P.S. (2018). Pengaruh Kepemimpinan Terhadap Kinerja Karyawan Yang Dimoderasi Oleh Motivasi Kerja Pada Bpr Se-Kecamatan Sukawati Gianyar. E-Jurnal Ekonomi dan Bisnis Universitas Udayana, 7.4 (2018):1107-1134

Goleman, D. (2000). Leadership that gets results. Harvard business review, 78(2), 4-17. http://www.academia.edu/download/33585213/HBR_MustReads_Managing_People.pdf\#page=4

Goleman, D. (2006). Emotional intelligence. Bantam. https://www.iitgn.ac.in/sites/default/files/library_files/2017/21082017.pdf

Goleman, D., Boyatzis, R. E., \& McKee, A. (2013). Primal leadership: Unleashing the power of emotional intelligence. Harvard Business Press. https://submissions.scholasticahq.com/api/v1/attachments/2941/download

Gunawan, A., Lin, C. H., Buttry, D. A., Mujica, V., Taylor, R. A., Prasher, R. S., \& Phelan, P. E. (2013). Liquid thermoelectrics: review of recent and limited new data of thermogalvanic cell experiments. Nanoscale and Microscale Thermophysical Engineering, 17(4), 304-323. https://doi.org/10.1080/15567265.2013.776149

Halim, F., \& Ishak, M. M. (2014). Post election behavior? Is it possible? A framework based on Hirschman (1970) model. Australian Journal of Basic and Applied Sciences, 8(12), 67-75. http://repo.uum.edu.my/12136/

Hardaningtyas, D. (2004). Pengaruh Tingkat Kecerdasan Emosi dan Sikap pada Budaya Organisasi Terhadap Organizational Citizenship Behavior (OCB) Pegawai PT (Persero) Pelabuhan Indonesia III (Doctoral dissertation, Universitas Airlangga). http://repository.unair.ac.id/35476/

Hardion, L., Dumas, P. J., Abdel-Samad, F., Kharrat, M. B. D., Surina, B., Affre, L., ... \& Baumel, A. (2016). Geographical isolation caused the diversification of the Mediterranean thorny cushion-like Astragalus L. sect. Tragacantha DC.(Fabaceae). Molecular phylogenetics and evolution,97, 187-195. https://doi.org/10.1016/j.ympev.2016.01.006

Herzberg, C. T. (1987). Magma density at high pressure Part 1: The effect of composition on the elastic properties of silicate liquids. Magmatic Processes: Physicochemical Principles, 1, 259-287.

Herzberg, C. T. (1987). Magma density at high pressure Part 1: The effect of composition on the elastic properties of silicate liquids. Magmatic Processes: Physicochemical Principles, 1, 259-287.

Herzberg, C. T. (1987). Magma density at high pressure Part 2: A test of the olivine flotation hypothesis. In Magmatic Processes: Physicochemical Principles (Vol. 1, pp. 47-58). Geochem. Soc. Spec. Publ..

Ibrahim, A. K., Kelly, S. J., Adams, C. E., \& Glazebrook, C. (2013). A systematic review of studies of depression prevalence in university students. Journal of psychiatric research, 47(3), 391-400. https://doi.org/10.1016/j.jpsychires.2012.11.015

Lawler III, E. E. (2000). Research directions. Human Resource Management Review, 10(3), 307-311. https://doi.org/10.1016/S1053-4822(00)00031-0

Lebi, M., Hruby, V. J., Ana, M. D. L., \& Hadley, M. E. (1989). Melanin concentrating hormone analogues: contraction of the cyclic structure. II. Antagonist activity. Life sciences, 44(7), 451-457. https://doi.org/10.1016/0024-3205(89)90460-8

Lestari, M. L., Müller, R. H., \& Möschwitzer, J. P. (2015). Systematic screening of different surface modifiers for the production of physically stable nanosuspensions. Journal of pharmaceutical sciences, 104(3), 1128-1140. https://doi.org/10.1002/jps.24266

Liu, N., Tang, M. L., Hentschel, M., Giessen, H., \& Alivisatos, A. P. (2011). Nanoantenna-enhanced gas sensing in a single tailored nanofocus. Nature materials, 10(8), 631. https://www.nature.com/articles/nmat3029 
Martini, N. N. P. (2013). Faktor-Faktor Yang Mempengaruhi Nilai Perusahaan Pada Perusahaan Publik Manufaktur Di Indonesia. Laporan Peneltian. Program Pascasarjana Universitas Brawijaya Malang.

Mitchell, T. R., \& Mickel, A. E. (1999). The meaning of money: An individual-difference perspective. Academy of management review, 24(3), 568-578. https://doi.org/10.5465/amr.1999.2202138

Nasution, A. H. (2006). Manajemen Industri. Yogyakarta: Penerbit Andi.

Nufus, H. (2011). Pengaruh organizational citizenship behavior (OCB) terhadap kinerja karyawan di PT. Putra Pertiwi karya utama. http://repository.uinjkt.ac.id/dspace/handle/123456789/4756

NURANINGSIH, P., \& Lantara, I. W. N. (2015). estimasi nilai wajar menara base tranceiver station (bts) kecamatan depok, kabupaten sleman guna optimalisasi pajak bumi dan bangunan (Doctoral dissertation, Universitas Gadjah Mada). http://etd.repository.ugm.ac.id/index.php

Organ, D. W., \& Lingl, A. (1995). Personality, satisfaction, and organizational citizenship behavior. The journal of social psychology, 135(3), 339-350. https://doi.org/10.1080/00224545.1995.9713963

Park, S. J., Jung, E. H., Ryu, R. S., Kang, H. W., Ko, J. M., Kim, H. J., .. \& Kang, H. Y. (2011). Clinical implementation of whole-genome array $\mathrm{CGH}$ as a first-tier test in 5080 pre and postnatal cases. Molecular cytogenetics, 4(1), 12. https://doi.org/10.1186/1755-8166-4-12

Pratama, F. A. (2016). Pengaruh Kecerdasan Emosional Terhadap Kinerja Karyawan Melalui Organizational Citizenship Behaviour pada Perusahaan Bersatu Sukses Group Surabaya. Jurnal Ilmu Manajemen (JIM), 4(2). http://jurnalmahasiswa.unesa.ac.id/index.php/jim/article/view/17518/15953

Purba, D. E., \& Seniati, A. N. L. (2004). The effect of personality and organizational commitment on organizational citizenship behavior. Makara of Social Sciences and Humanity Series, 8(3), 105-11.

Rahmasari, L. (2016). Pengaruh Kecerdasan Intelektual, Kecerdasan Emosi dan Kecerdasan Spiritual Terhadap Kinerja Karyawan. Majalah Ilmiah Informatika, 3(1). http://www.unaki.ac.id/ejournal/index.php/majalah-ilmiahinformatika/article/view/58/94

Robbins, S. P., \& Judge, T. A. (2006). Perilaku organisasi. Edisi kesepuluh. Jakarta: PT Indeks Kelompok Gramedia. http://www.academia.edu/download/43791329/RESUME_PERILAKU_ORGANISASI.docx

Salovey, P., Mayer, J. D., Caruso, D., \& Lopes, P. N. (2003). Measuring emotional intelligence as a set of abilities with the Mayer-Salovey-Caruso Emotional Intelligence Test. https://psycnet.apa.org/doi/10.1037/10612-016

Sayekti, A., \& Kartika, L. (2016). Perancangan Model Peningkatan Kapasitas Sumber Daya Manusiadi Bank Perkreditan Rakyat (BPR). Jurnal Aplikasi Manajemen, 14(2), $217-232$. http://dx.doi.org/10.18202/jam23026332.14.2.04

Setyawati, M. I., Tay, C. Y., \& Leong, D. T. (2013). Effect of zinc oxide nanomaterials-induced oxidative stress on the p53 pathway. Biomaterials, 34(38), 10133-10142. https://doi.org/10.1016/j.biomaterials.2013.09.024

Simanjuntak, F. S. H., Kim, T. K., Lee, S. D., Ahn, B. S., Kim, H. S., \& Lee, H. (2011). CaO-catalyzed synthesis of glycerol carbonate from glycerol and dimethyl carbonate: Isolation and characterization of an active $\mathrm{Ca}$ species. Applied Catalysis A: General, 401(1-2), 220-225. https://doi.org/10.1016/j.apcata.2011.05.024

Spector, P. E. (1997). Job satisfaction: Application, assessment, causes, and consequences (Vol. 3). Sage publications. https://books.google.co.id/books?hl=en\&lr=\&id=_-AXCgAAQBAJ\&oi

Tang, T. L. P., \& Chiu, R. K. (2003). Income, money ethic, pay satisfaction, commitment, and unethical behavior: Is the love of money the root of evil for Hong Kong employees?. Journal of business ethics, 46(1), 13-30. https://doi.org/10.1023/A:1024731611490

Ticoalu, L. K. (2013). Organizational citizenship behavior (OCB) dan komitmen organisasi pengaruhnya terhadap kinerja karyawan. Jurnal EMBA: Jurnal Riset Ekonomi, Manajemen, Bisnis dan Akuntansi, 1(4). https://ejournal.unsrat.ac.id/index.php/emba/article/view/2806

Trihandini, M. F. AR 2005 Analisis Pengaruh Kecerdasan Emosinal, Kecerdasan Intelektual, dan Kecerdasan Spiritual Terhadap Kinerja.

Vohs, K. D., Mead, N. L., \& Goode, M. R. (2008). Merely activating the concept of money changes personal and interpersonal behavior. Current Directions in Psychological Science, 17(3), 208-212. https://doi.org/10.1111\%2Fj.1467-8721.2008.00576.x

Wibowo, S., \& Deng, H. (2015). Multi-criteria group decision making for evaluating the performance of e-waste recycling programs under uncertainty. Waste Management, 40, 127-135. https://doi.org/10.1016/j.wasman.2015.02.035

Widiani, N. P., Putri, A. M. A. D., Sari, M. M. R., \& Wirajaya, I. G. A. (2019). The effect of love of money and emotional intelligence on employee performance with organizational citizenship behavior as mediating variable. International Research Journal of Engineering, IT \& Scientific Research, 5(1), 39-49. https://doi.org/10.21744/irjeis.v5n1.596 
Wiguna Giri, D. B. Keadilan Distributif, Keadilan Prosedural, dan Komitmen Tujuan Anggaran sebagai Pemediasi Partisipasi Penganggaran pada Kinerja Manajerial. E-Jurnal Ekonomi dan Bisnis Universitas Udayana, 3. https://ojs.unud.ac.id/index.php/EEB/article/view/7912 


\section{Biography of Authors}

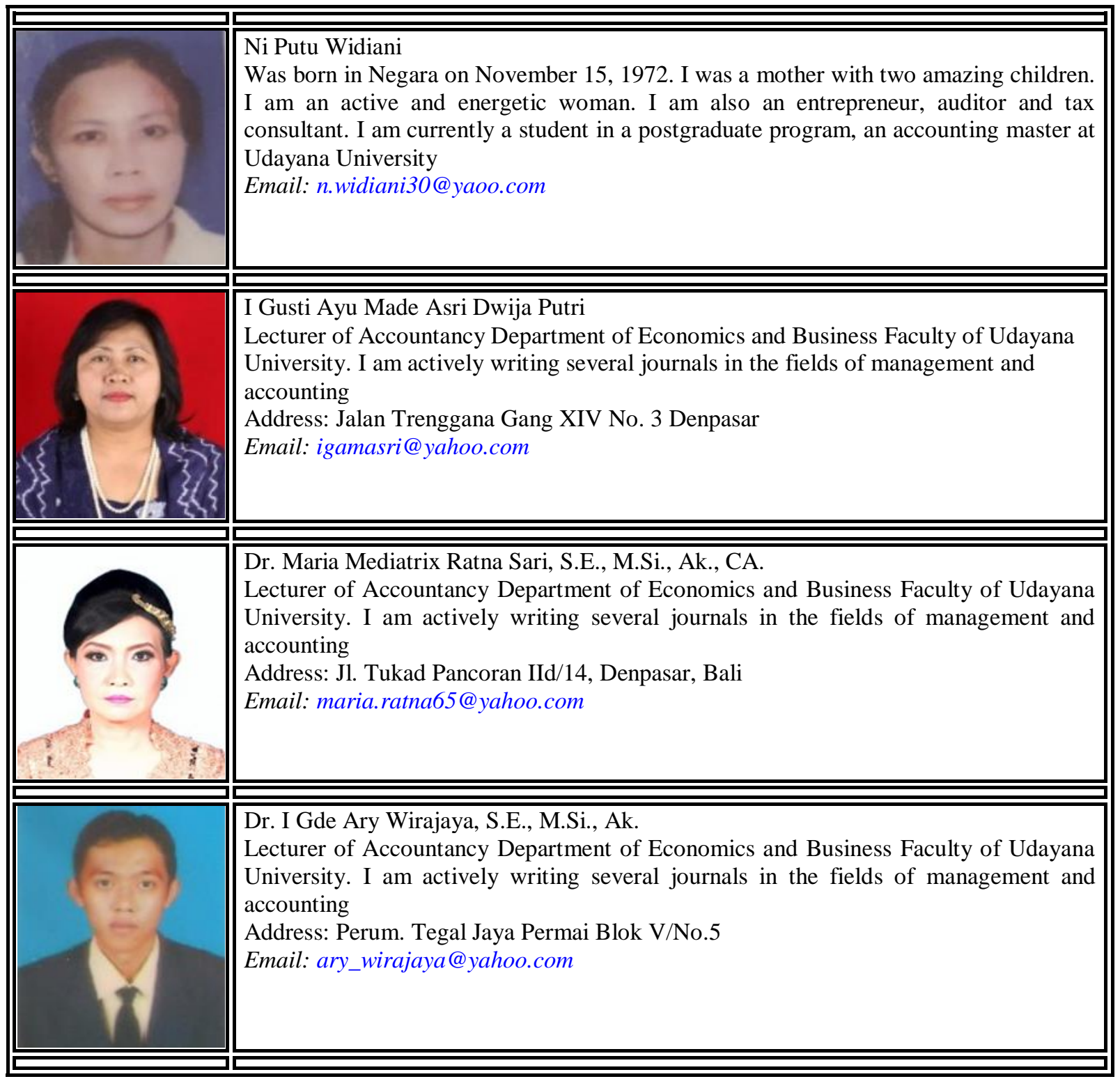

Widiani, N. P., Putri, A. M. A. D., Sari, M. M. R., \& Wirajaya, I. G. A. (2019). The effect of love of money and emotional intelligence on employee performance with organizational citizenship behavior as mediating variable. International Research Journal of Engineering, IT \& Scientific Research, 5(1), 39-49. https://doi.org/10.21744/irjeis.v5n1.596 